\title{
Effect Of Corporate Social Responsibility Performance On Stakeholder's Perception Of Telecommunication Companies In Nigeria (A Study Of Mtn, Globalcom \& Etisalat)
}

\author{
Arzizeh T. Tapang ${ }^{1}$, Bassey E. Bassey ${ }^{2}$ \\ ${ }^{1 *}$ Department of Accounting, College of Management Sciences, Michael Okpara University of Agriculture \\ Umudike, P.M.B. 7267 Umuahia, Abia State - Nigeria, \\ 2 Department of Accounting, Faculty of Management Sciences, University of Calabar, P.M.B. 1115 Calabar, \\ Cross River State - Nigeria
}

\begin{abstract}
This study aimed at determining the effect of corporate social responsibility performance on stakeholder's perception of telecommunication companies in Nigeria. An ex-post facto research design was employed. Data were collected and statistically analysis using multiple regression. Based on the empirical analysis, the study revealed that economic expectation of CRS performance do has a significant effect on stakeholder's perception. The study also revealed that legal expectation of CRS performance do has a significant effect on stakeholder's perception. The study further revealed that ethical expectation of CRS performance do has a significant effect on stakeholder's perception. The study finally revealed that discretional expectation do has a significant effect on stakeholder's perception. Conclusively, behaving in a socially responsible way normally raises the cost profile of a firm, there have been evidence, although not unchallenged, that firms that do so tend to enjoy better long run corporate performance, arising mostly from the support, friendliness and peace they often experience in their operating environment. The study therefore recommended that firms should institute proactive waste management systems and structures that ensure that the disposals of the harmful by-products in every aspect of their operations are properly handled. Such systems need not be compelled by government regulation, but should be voluntarily provided by the firms themselves. The long run benefits of avoidance of fines and penalties justify such expenditure. Corporate social responsibility projects should be provided by firms especially within and for the benefit of their host communities, especially as government has not been very successful in meeting the basic needs of most communities. Typical areas of intervention for firms in Nigeria include education, health and physical infrastructure support. Such actions ensure that a firm enjoys a positive image and good neighborliness from its host community.
\end{abstract}

Keywords: Community investment, Corporate social responsibility, Discretional / Philanthropic expectation, Economic expectation, Ethical expectation, Legal expectation, Stakeholder's perception.

\section{Introduction}

In recent years, scholars and managers have devoted greater attention to the strategic implications of Corporate Social Responsibility (Fung \& Rui, 2002). Where a firm goes beyond compliance with laid down rules and regulations or its pecuniary interest and engages in activities or takes actions that appear to further some societal good, it is considered to be engaging in corporate social responsibility (Mcwilliams \& Siegel, 2001). Corporate Social Responsibility (CSR) activities include incorporating social characteristics or features into products and manufacturing processes (e.g. aerosol products with no fluorocarbons or using environmentally-friendly technologies), adopting progressive human resource management practices (e.g. promoting employee empowerment), achieving higher levels of environmental performance through recycling and pollution abatement (e.g. adopting an aggressive stance towards reducing emissions), and advancing the goals of community organizations (e.g. working closely with groups) (Mcwilliams \& Siegel, 2001).

Since the dawn of industrial revolution maximization of the wealth of shareholders has been the focal point of most corporate strategies (Mcwilliams \& Siegel, 2001). The only aim of corporations is to earn profit for their shareholders has undergone a paradigm shift and most firms today have come to the realization that they can best create shareholder wealth by creating societal wealth, through meeting the expectations of the larger society (Freeman, 1970). Corporate Social Responsibility (CSR) is an outgrowth of the school of thought that businesses must look beyond shareholder interests or compliance with legal requirements and contribute to the social, ethical, environmental, economic and other causes (Freeman, 1984). Advocates view CSR as a social and moral responsibility of the businesses. 


\subsection{Statement of the problem}

The most common and most well documented of the failures in corporate social responsibility is stakeholder's dissatisfaction with managerial performance. Poor performance will create stakeholders dissatisfaction. The basic problem of corporate social responsibility is that despite the revenues generated by telecommunication firms they are accused of being insensitive about the interest of stakeholders. They are similarly accused of being insensitive to demands to interpret the public preferences and to formulate courses of action aimed at implementing these preferences even before government action stipulates what sh4ould be done. Telecommunication companies are confronted with increasing demands for social responsibility and are held responsible for environmental problems arising from their operations. The performance and success of these companies depends on how well they are able to manage their relationship with stakeholders. Despite all their efforts to render social responsibility to its stakeholders, it has not succeeded in creating conducive conditions to promote stakeholders human dignity and respect. Therefore this study is meant to investigate the extent to which corporate social responsibility performance affects stakeholders perception of telecommunication companies in Nigeria.

\subsection{Objectives of the study}

The main objective of this study is to investigate the extent to which corporate social responsibility performance affects stakeholder's perception of telecommunication companies in Nigeria.

The specific objectives of this study are:

1. To examine the extent to which the economic expectation of corporate social responsibility performance affects stakeholder's perception.

2. To determine the extent to which legal expectation of corporate social responsibility performance affects stakeholder's perception.

3. To investigate the extent to which ethical expectation of corporate social responsibility performance affects stakeholder's perception.

4. To ascertain the extent to which discretional/philanthropic expectation of corporate social responsibility performance affects stakeholder's perception.

\subsection{Research questions}

The research questions for the study are:

1. To what extent does economic expectation of corporate social responsibility performance affects stakeholder's perception?

2. To what extent does legal expectation of corporate social responsibility performance affects stakeholder's perception?

3. To what extent does ethical expectation of corporate social responsibility performance affects stakeholder's perception?

4. To what extent does discretional/philanthropic expectation of corporate social responsibility performance affects stakeholder's perception?

\subsection{Research hypotheses}

The research hypotheses stated in null form are as follows:

1. Economic expectation of corporate social responsibility performance has no significant effect on stakeholder's perception.

2. Legal expectation of corporate social responsibility performance has no significant effect on stakeholder's perception.

3. Ethical expectation of corporate social responsibility performance has no significant effect on stakeholder's perception.

4. Discretional/philanthropic expectation of corporate social responsibility performance has no significant effect on stakeholder's perception.

\subsection{Conceptual framework}

\section{Review Of Related Literature}

Corporate social responsibility has to do with an organization going out of his way to initiate actions that will impact positively on its host community, its environment and the people generally. It can be seen as a way of acknowledging the fact that some business fall outs have adverse effects on the citizens and society and making efforts to ensure that such negative impact are corrected. Posk, Omotesho, Tsoho and Ajayi (1999) as a matter of fact, believe that corporate social responsibility means that a corporation should be held accountable for any of its actions that affect people, communities, and its environment. It implies that negative business 
impacts on people and society should be acknowledged and corrected, if possible. It may require a company forgoing some profits if its social impacts are seriously harmful to some of its stakeholders or if its fund can be used to promote a positive social good.

Various views on CSR have been expressed over the years, with Bowen's view expressed in his 1953 publication of Social Responsibilities for the Businessman, reportedly considered by many as definitive on the subject (Lee, 2008). Most authors argued in favour of CSR, despite the lack of consensus on what it really meant. However, Friedman (1962) promoted a contrary viewpoint by asserting that "businesses had no other social responsibility than to make as much profit as possible". McGuire (1963), while agreeing that economic concerns are important to businesses, argued that "the idea of social responsibilities supposes that the corporation has not only economic and legal obligations, but also certain responsibilities to society which extend beyond these obligations".

Other considerations in CSR definition exist. One of which is Carroll's (1979) four-part definition of CSR which encompasses the economic, legal, ethical and discretionary (philanthropic) expectations that society has of any given organization; namely:

$>$ be profitable (economic),

$>$ be obedient to laws and regulations (legal),

$>$ do what is right, fair and just (ethical), and;

$>$ Be good corporate citizens (philanthropic / discretionary).

Most corporate organizations subscribe to the four parts but feel more obligated to the first three. Visser (2006) argued against Carroll's CSR model, and postulated CSR practice as a socio-cultural product that reflects the society and people in which the corporate bodies operate. Chandler (2001) argued that "while there is no universal definition for CSR, it generally refers to transparent business practices that are based on ethical values, compliance with legal requirements, and respect for people, communities and the environment' (p. 43). Thus, beyond making profits, companies are responsible for the totality of their impact on people and the planet.' This is tantamount to saying that beyond profit, corporate bodies need to address issues of importance to the people and the environment. Similarly, the World Business Council for Sustainable Development (2002), after consulting various stakeholders, stated that CSR is the commitment of businesses to contribute to sustainable economic development, working with employees, their families, the local community, and society at large to improve their quality of life.

Mate (2002) sees CSR as having five themes (human rights, worker rights, environmental impact, community involvement, and supplier relations \& monitoring). These themes reflect in company's core values and impinge on its policies, strategies, decision-making and operations. In addition, different corporate entities tend to come with their own concepts of CSR which is reflected in their core values and their CSR interventions. Accordingly, McWilliams and Siegel (2001), CSR refer to situations where a firm carries out "actions that appear to further some social good, beyond the interests of the firm and that which is required by law." This definition sees CSR as voluntary actions by a corporate entity pursuant of social good. The World Economic Forum (2003) sees corporate citizenship as the contribution a company makes to society through its core business activities, its social investment and philanthropy programmes, and its engagement in public policy. The manner in which a company manages its economic, social and environmental relationships, as well as those with different stakeholders, in particular shareholders, employees, customers, business partners, governments and communities determines its impact. CRS interventions hence involves the investment of the firm's resources in pro bono work, philanthropy, support for community education and health, and protection of the environment that are seen as parts of the company's social performance (Wood, 1991).

Discussing the motives for pursuing CSR, Jones (1995) argued that companies involved in transactions with stakeholders on the basis of trust and cooperation are motivated to be honest, trustworthy and ethical because there are high returns to such behaviour. Dwelling further on this argument, Fombrun and Shanley (1990) demonstrated that the reputation of the firm is affected by its socially responsible behaviour. This implies that a firm should consider CSR as an element of its corporate strategy. Some authors (Bagnoli and Watts, 2013; Baron, 2001; McWilliams and Siegel, 2001) assert that firms engage in "profit-maximizing" CSR. That is, companies behave in a socially responsible manner because they anticipate some benefits from these actions. Such benefits may be a social license to operate which, in troubled regions, minimizes the down-times as results of shutdowns, shut-ins and lock-outs. Other potential benefits of CSR include enhancement of reputation and goodwill which further the ability to retain customers in spite of price hikes. These benefits are deemed to compensate for the extra costs incurred in implementing CSR.

Extending the discussion on the motive for CSR further, Baron (2001) and; McWilliams and Siegel (2001) formulated the profit-maximizing CSR model. Baron (2001) used the phrase "strategic CSR" and defined as the "private provision of a public good." Some companies report annually on their CSR activities, probably because they anticipate some returns to the provision of information to the public on their contributions to social 
good. Such information are however regarded by some members of the public as self-promoting and biased. It is because of such perceptions that some multi-nationals engage external auditors to audit their CSR activities.

To be able to understand CSR from a Nigerian perspective it is of value to explore the drivers for, and the history and development of CSR in Nigeria. The World Business Council for sustainable Development has discussed CSR with business and non-business stakeholders in a number of countries in the world with the objective of understanding local perspectives better and to get different perceptions of what CSR should mean from a number of different societies. (http:www.cecodes.org.co). One important finding in this study was that people were talking about the role of the private sector in relation to a social agenda and they saw that role as increasingly linked to the overall well-being of society. Therefore the chosen priorities differed according to the perception of local needs. The key CSR issues identified in the study included Human rights, Employee rights, Environmental protection, Community involvement and Supplier relations. The book "Corporate Citizenship in Developing Countries" (Pedersen and Huniche, 2006) contains a chapter about revisiting Carroll's CSR pyramid from a Nigerian perspective. Most of the research on Carroll's CSR pyramid has been in an American context and in this report an attempt is made to look on how CSR manifests itself in a Nigerian context. In Nigeria, economic responsibility still get the most emphasis while philanthropy is given second highest priority, followed by legal and then ethical responsibilities.

According to the report there are many reasons for this. Firstly, the socio-economic needs of the Nigeria societies in which companies operate are so huge that philanthropy has become an expected norm. Companies also understand that they cannot succeed in societies that fail. Secondly, many Nigerian societies have become dependent on foreign aid and there is an ingrained culture of philanthropy in Nigeria. A third reason, according to the report, is that CSR is still at an early stage in Nigeria, sometimes even equating philanthropy. It is important to stress that in Nigeria philanthropy is more than charitable giving. HIV/AIDS is an example where the response by business is essentially philanthropic but clearly in companies own economic interests. The low priority for legal responsibilities is, according to the study, not due to the fact that Nigeria companies ignore the law but the pressure for governance and CSR is not so immense. Ethical perspective seems to have the least influence on the CSR agenda. This is not to say that African businesses are unethical. For example, the King Report in 2003 (http://www.corporate compliance. org) was the first global corporate governance code to talk about 'stakeholders' and to stress the importance of business accountability beyond the interests of shareholders. Ajadi (2006), in a conference paper on Corporate Social Responsibility in Nigeria delivered at British Council conference on CSR in Nigeria, 2006, specifies some additional specific drivers for CSR in Nigeria:

- The failure of centralized, government controlled economy to develop the country.

- The extraordinary transaction cost to business of corruption and other failures of social capital.

- The history of conflict and waste in the extractive industry exemplified by the Niger Delta saga.

- The Nigerian population whose majority is under the age of 25 and is largely ignored despite the fact that they are critical to the survival and future prosperity of business and the country at large.

- The potential benefit of a commercially active and productive country of over 140 million potential consumers.

The drivers for CSR in the west are to be found within areas such as increased brand value, greater access to finance, a healthier and safer workforce, stronger risk management and corporate governance, motivated people, customer loyalty, enhanced confidence and trust of stakeholders as well as enhanced public image. These drivers may not necessarily be applicable to Nigerian companies. Most indigenous companies in Nigeria are privately held, family owned and operated. Local consumer and civil society pressures are almost nonexistent and law enforcement mechanisms are weak (Amaeshi, Adi, Ogbechie \& Amao. 2006). There are numerous ways of implementing CSR in an organization. CSR practices can address environmental issues, social issues or both. The implementation can be done by integrating CSR in the business or it can be run as a project. Sometimes there are CSR strategies and policies framing the CSR agenda, sometimes there are not. According to world Business Council for sustainable Development (Lohman and Steinholtz, 2013) an active CSR work might include areas such as:

- The management of the organization clearly declares its views and obligations towards the society and its stakeholders.

- The organization develops and implements clear policies.

- The organization has rules for purchasing including social and environmental concerns.

- The organization reduces its "ecological footprints", both in production and in the process of production.

- The organization has objectives with regard to environmental and social concerns.

- The organization shows an active engagement with regard to the development of its local society.

- Consumers are educated on how products ought to be used.

- The organization informs about all its different business areas in a transparent manner. 
For most businesses operating in Nigeria whether small or large, local or national, the transaction cost of operating is often unpredictable. At the heart of this difficulty is the obvious problem of operating in a low trust economy. For many businesses the cost of paying upfront on cash flow or delayed payment; the difficulty of investing in people development; the challenge of high volume cash transactions are all part of a severely eroded social capital. At the core of this issue is the role of business partnership with government and others to exemplify and model behaviors that restore optimism and improves trust. The challenges that face a business in Nigeria are unique because CSR can probably not be optional in such a climate. In a country where the social, health, education and environmental needs are so prevalent, where government resources are so stretched, where everyday people live on the breadline, business any other way is not only unethical, it is most probably not sustainable.

\subsubsection{Definition of corporate social responsibilities}

There are a myriad of definitions of Corporate Social Responsibilities [CSR], each considered valuable in their own right and designed to fit the specific organization. The majority of definitions integrate the three dimensions to the concept, that is, economic, environmental and social dimensions. CSR had also been commonly described as "a demonstration of certain responsible behavior on the part of public and the private [government and business] sectors toward society and the environment".

Business for Social Responsibility (BSR), a leading Global Business partner, in a Forum held in 2006 defined CSR as achieving commercial success in ways that honors ethical values and respect people, communities, and the natural environment. For BSR, CSR also means addressing the legal, ethical, commercial and other expectations society has for business, and making decisions that fairly balance the claim of all key stakeholders. In its simplest terms, it is: "what you do", "how you do it" "and when and what you say". In this sense, CSR is viewed as a comprehensive set of policies, practices and programmes that are integrated into business operations, supply chain, and decision making processes throughout the company and wherever the company does businesses that are supported and rewarded by top management. It also includes responsibility for current and past actions as well as future impacts. The issues that represent a company's CSR focus vary by business, size, sector and even geographical region. It is seen by leadership of companies as more than a collection of discrete practices or occasional gestures or initiatives motivated by marketing, public relations or other business benefits. Also, the World Business Council on Sustainability Development, 1998 described CSR as "the continuing commitment by Business to behave ethically and contribute to economic development while improving the quality of life of the workforce and their families as well as of the local community and society at large". "CSR is the concept that an enterprise is responsible or accountable for its impact on all relevant shareholders" [European Union, 2006]. According to Macmillan [2005], “CSR is a term describing a company's obligation to be accountable to all its stakeholders in all its operations and activities.

Socially responsible companies will consider the full scope of their impact on communities and the environment when making decisions, balancing the need of stakeholders with their need to make a profit". "CSR is concerned with treating the stakeholders of the firm ethically or in a socially responsible manner. Since stakeholders exist both within a firm's and outside a firm, hence, behaving socially and responsibly will increase the human development of stakeholders both within and outside the corporation" [Clarkson, 1995].

A reputable author, Kenneth Andrews Steiner (1977) defined Corporate Social Responsibilities (CSR) "as the intelligent and objective concern for the welfare of the society that retains the individual and corporate behavior from ultimately destructive activities, no matter how immediately profitable and leads to the directions of positive construction of human betterment". As an improvement on the above definitions, Koontz and O'Donnell (1968) defined social responsibility as the personal obligation of everyone, as he acts in his own interests, but he must always have due regard that his freedom does not restrict others from doing the same thing. He further noted that a socially responsible individual or organization will obey the laws of the land because the rights of others are at stake. In emphasizing the ecological conceptualization of social responsibility, Buchholz (1991) noted that any good definition of social responsibility must contain if not all, most of the following; Responsibility that:

1. Goes beyond the production goods and services at a profit.

2. Helps in solving important social problems those that the organizations are responsible for creating.

3. Makes corporations have greater constituency than stockholders alone.

4. Makes corporations have great impacts that goes beyond marketplace transactions, and

5. Makes corporations serve a wider range of human values that can be captured by a sole focus on value.

CSR can therefore be referred to as decisions and actions taken by organizations for reasons at least, particularly beyond the organization's direct economic or technical interest. For many corporate bodies giving to charities is a struggle really, their objective do not usually build-in the strategic need to support the communities 
that they serve. The focus totally is to maximize profit or financial returns. The thrust of their arguments centre around balancing their obligations to stakeholders, corporate social responsibilities should be strategic no doubt. Engaging in strategic philanthropy is done by even the best corporate bodies in the world. It should however have an underlying compassionate foundation. There should be a symbiotic relationship between corporate organization and the host communities, a sort of on-going reconciliation between the organization's economic orientations. There should be an unwritten "social contract", so that it should not be forced responsibility like Education Trust Fund tax but a voluntary social service based on the needs of the community.

Socially responsible business practice implies that CSR is the social practice where the corporation adapts and conducts discretionary business practices and investments that support social causes to improve community well-being in order to protect the environment. Key distinctions include focus on activities that are discretionary, not those that are mandated by laws or regulatory agencies or are simply expected, as with meeting moral standards. Community is interpreted broadly to include employees of the corporation, suppliers, distributors, non-profit and public sector partners as well as members of the general public. And well-being can be referred to health and safety as well as psychological and emotional needs. It is also about capacity building for sustainable livelihoods, respect for cultural difference and finds a business in building the skills of employees, the community and the government. Indeed it is about business giving back to society. Generally speaking, Corporate Social Responsibility, irrespective of the sector refers to:

1. A collection of policies and practices linked to relationship with key stakeholders, values, compliance with legal requirements, and respect for people, communities and the environment.

2. The commitment of business to contribute to sustainable development.

According to the European Commission, CSR involves companies integrating "social and environmental concerns into business operations and in their interaction with stakeholders on a voluntary basis". The key to this definition lies in the word "voluntary". According to Nigeria Social Enterprise Reports Vol.2, CSR is generally understood to be the way a company achieves a balance or integration of economic, environmental and social imperatives while at the same time addressing shareholders and stakeholders expectations. It went further to say that CSR is generally seen as the contribution of business to sustainable development which has been defined as "development that meets the needs of the present without compromising the ability of the future generations to meet their own needs".

\subsubsection{Characteristics of corporate social responsibilities}

The European Foundation for Quality Management [EFQM] presents some common characteristics for CSR which are:

1. Meeting the need of current stakeholders without compromising the ability of future generations to meet their own demand.

2. Adopting CSR voluntarily, rather than as legal requirement, because it is seen to be in the long-term interests of the organization.

3. Integrating social, environmental and economic policies in day to day business

4. Accepting CSR as a core activity that is embedded into an organization's management strategy.

The three dimension of CSR with specific examples of areas particular to each dimension are:

\section{A. Economic responsibility}

Integrity, corporate governance, economic development of the community, transparency, prevention of bribery and corruption, payments to national and local authorities use of local suppliers, hiring local labour and similar areas.

\section{B. Social responsibility}

Human rights training and developing local labour, contributing expertise to community programs and similar areas.

\section{Environmental responsibility}

Precautionary approaches to prevent or minimize adverse impacts support for initiatives, promoting greater environmental responsibility, developing and diffusing environmentally friendly technologies and similar areas. Lohman and Steinholtz (2013) view the CSR concept as a combination of three separate agendas, namely Corporate Sustainability, Accountability and Governance. Corporate Sustainability derives from the United Nation meeting in Rio de Janeiro in 1992 and the Agenda 21. This refers to how we address and balance the social, economic and environmental areas in the world so that our long term survival is not threatened. Corporate Accountability focuses on the credibility of the organization and is used in situations where discussions are held about the ability of the organization to manage. 
Corporate governance is used in the discussion about how an organization is being run. It deals with transparency and in the long run trustworthiness. Bowen (1953) defined it as the obligation of business men to pursue those policies, to make those decisions, or to follow those lines of action which are desirable in terms of objectives and values of the society.

A number of studies have been carried out on CSR since the idea was floated in the twentieth century. For, example, a Business week/Harris poll (1993) revealed that U.S. top-level corporate executives (69\% of those polled) and MBA students (89\%) believed that corporations should be more involved in solving crucial problems. Also in a study of 107 Europeans corporations, majorly of the chief executives cadre surveyed agreed that addressing social issues, such as substance abuse, health care and education, was needed (Mathison, 2003). Business in any society needs to take responsibility, for every decision that is made, every action that is taken, must be viewed in the light of that kind of responsibility. Social responsibility requires business organizations to balance the benefits to be gained against the costs of achieving those benefits. There is the general belief that both business and society gain when firms actively strive to be socially responsible. While business organizations gain in enhanced reputation, society gains from the social projects executed by the business organization.

In the early 1970s, companies began to appreciate community service as a way to improve their images, internally and externally, as well as to serve the communities in which the business operates. A study carried out by the National Volunteer Centre in U.S. in 1977 shows that more than 1,100 major U.S. corporations had established structured activities to involve their workers in community volunteerism by 1990 . A survey of 180 leading U.S. companies found that $79 \%$ of them had volunteer programmes. Also, a study conducted by IBM and the graduate of School of Business at the University of Columbia in 1994 showed a clear link between volunteerism and return on assets, return on investments and employee productivity. A company with a strong community involvement programme is likely to score high in profitability and employee morale. Social responsibility should, in fact, reflect cultural values and may differ in forms from one society to the other. What is socially acceptable in Japan may differ in forms from that of Germany, Brazil or Indonesia.

Japanese firms have proved themselves models citizens on many dimensions of Corporate Social Responsibility. Their support of local community activities and other philanthropic endeavours have led to increased goodwill in the communities where they operate. The firms help society in areas directly related to the operations of the business. A survey conducted by the Japanese External Trade Organisation (JETRO) in 1997 shows that approximately $80 \%$ of Japanese affiliated operations in the United State which were covered by the survey engaged in corporate philanthropy. Making cash contributions was the most common form of philanthropy (about 91\%). Community development and education were the primary beneficiaries of cash donations and encouragement of employee volunteerism was up to $36 \%$ from 1992 . Over $95 \%$ of responding organizations maintained or increased both cash donations and other philanthropic activities since the last survey in 1992. Being socially responsible by meeting the public's continually changing expectations requires wise leadership at the top of the organization. Miles (1987) observed that "corporate leaders who possesses this kind of social vision believe that business should help create social change rather than block it. With such attitude, they know that their own company will have a better chance of surviving in the turbulent social currents of today's world". Frooman (1997) further observed that companies which are socially responsible are guided by enlightened self interest, which means that they are socially aware without giving up their own economic self interest. Profits are the reward for the firm as it continues to provide true value to its customers, to help its employees to grow, and to behave responsibly as a corporate citizen. An emphasis on social responsibility can attract customers. A poll conducted by Opinion Research Corporation shows that $89 \%$ of purchases by adult are influenced by a company's reputation. Social responsibility also benefits companies by enabling them to recruit a high quality labor force. The reputation of the firm and the goodwill associated with socially responsible actions attract talented prospective employee, that is, people seeking an employer for whom they would be proud to work.

At Cadbury Nigeria plc, the concept of CSR is seen as a continuing commitment by business to behave ethically in ways that will contribute to economic development of the nation. It is also expected to improve the quality of life of not only the company's workforce and families but also that of the local community as well as the society at large. (Business Day, Newspaper, 13th October, 2003) Over the last decades there has been an apparent shift from adopting more responsible business practices as a result of regulatory citations, consumer complaints and special interest group pressures, to proactive research exploring corporate solutions to social problems and incorporating new business practices that will support these issues. This shift has been due to:

1. Increasing evidence being documented and shared, demonstrating that socially responsible business practices can actually increase profits.

2. The fact that in our global market place, consumers have more options and can make choices based on the criteria beyond product, price and distribution channels. Research emphasized that consumers are also basing their purchase decisions on reputation for fair and sustainable business practices and perceptions of commitment to the community's welfare. 
3. The fact that Investors and other stakeholders may also be the driving force with increased public scrutiny and use of more sophisticated pressure tactics, including use of technology and power of internet.

4. Interest in increased worker productivity and retention which has turned corporate heads towards ways to improve satisfaction and well being.

5. Technology and increased third party reporting having been given increased visibility and coverage of corporate activities, especially when things go wrong, as with current corporate scandals that have made the public more suspicious of business creating the need for business to put a positive shine on their activities.

6. The bar for full disclosure appears have been raised, moving potential customers from a "consumer beware" attitude to an expectation that they will be fully informed as regards practices including product content, sources of raw materials and manufacturing processes.

Advocate of CSR argues that companies with good social and environmental records will perform better in the long run than those that do not behave responsibly. This is because customers will like to patronize any company with good social and environmental records more than companies without such records as they will be seen to have identified with the community. It has been argued that since Corporate Social Responsibility can enhance a company's image, it raises the question of whether or not CSR was embarked upon solely for corporate self interest, company or their chief executives may be politically motivated when making corporate donations. But Black (1989) objecting to this self interest motive maintains that in CSR, the company giving funds does not attempt to gain any advertising benefit or undue identification. The company is contented with the belief that CSR is good business.

\section{Responsibilities of a firm}

To achieve set objectives, every firm owes various duties to all the stakeholders, and these must be fulfilled. These responsibilities are discussed below:

1. Duty to protect the well-being of people in its environment. A firm's primary duty is to protect the well being of those living in its environment; its operations or practice. For example, a firm wishing to carry out banking business must first be incorporated under the Companies and Allied Matter Act (CAMA), 1990 and then valid license from the governor of the Central Bank of Nigeria (CBN). Its operations should be in line with the provisions of the Bank and Other Financial Institutions Acts (BOFIA), 1991, the CBN Act, the Nigerian Deposit Insurance Corporations (NDIC) Acts, the Money Laundry Act 2004 and other banking laws.

2. The firm should produce goods and services that are not harmful to the people. A manufacturing company should not produce goods that may cause death to people. Similarly, in the course of maximizing profit, a bank should not finance illegal projects, say, provide finance for the illegal purchase of ammunition, or albeit illegal transfer by unpatriotic citizens or politicians.

3. A firm should not deceive others. Deception, in this way, can take various forms, namely; failing to include all the required quantities and quality materials for producing a particular product, but may still indicate on the package that the normal quality were involved; colluding with the external auditor to render false financial statements to shareholders, regulating authorities and members of the public, with a view to declaring false profit; preparing two sets of accounts or returns, i.e. accurate and false accounts, and sending the false one to the regulatory authorities and the accurate one to the shareholders, to conceal some facts in the course of bank supervision and examination.

4. An organization should enter into fair binding contract with its customers, creditors, employees, suppliers etc. all terms and conditions of the contract should be well stated by the firm and well understood by the parties concerned. It is important for a firm to discharge its duties under the contract at all times. For example, a customer granted credit facility should be allowed to repay under the agreed terms and conditions for which the loan was granted.

5. Duty to make reasonable return to shareholders in accordance with the level of investment. The ordinary shareholder takes the highest risk in business, hence it is the duty of management of a company to utilize the resources of the company effectively to generate profit, the bulk of which should go to the ordinary shareholder. The firm should ensure that the market price of the company's share is attractive to the public. When this is done, the owner's economic welfare is maximized through high return on capital usually reflected on the market price of shares of the company.

6. Duty to minimize harmful effect of substance. In the course of doing business, firms are bound to engage in activities whose effects may be harmful or distasteful to the members of the organization and the public. For example, hospital, police, radio, and television stations, telecommunication business provide twentyfour hours service to their customers and client, an indication that the employees of these organizations must be on duty every hour of the day. To be effective and efficient, there is need for shift duty. Although coming to work at night or very early in the morning might not be palatable with all employees, this is in 
evitable; thus, a fair compensation, in terms of shift hazards and inconvenience allowances, should be paid to the employees concerned. This will strengthen their commitment. Similarly oil and gas industries should pay high compensation to the people living in the area where oil and gases are produced, as this could compensate for the environment degradation of the area and other problems encountered by the people living in the community. Also bank staff that work outside the normal banking hours should be paid compensation allowance.

7. Duty to pay reasonable salaries and wages to the employees. It is the duty of the firm to use the revenue generated from its business activities to pay fair and reasonable compensation in the forms of salaries and allowances to workers. This should be commensurate with the services rendered. However, it will be unethical, unfair and an act of irresponsibility for a firm to ask the workers to perform task that will expose them to serious danger, risk, or unprofessional practices, all in the interest of robust salaries and allowances. For example, a situation where banks set unachievable deposit targets for staff by employing 'beautiful' ladies and 'handsome' men to run after money-bags to attract deposits. This encourages fraud and prostitution. A staff that fails to meet the target knowing full well that he would be sacked might resort to stealing to raise more funds or resort to prostitution. In like manner, a firm that pays reasonable returns on capital will enjoy continuous investment of shareholders.

8. Duty to use part of the firm's profit to provide amenities that promote the common good of the community in which it operates.

9. Duty to embark on projects that brings about the expansion and improvement in the company's operations. Firms that expand create additional employment opportunities to the community, and this will lessen crime rates. Similarly goods are made available at affordable prices, thereby meeting the needs and satisfaction of the consumers. This encourages good standard of living of people in the community.

10. Duty to honor obligations to the government in terms of payments of taxes an levies, thereby making fund available to the government to provide infrastructure facilities and meet the recurrent expenditures with a view to promoting national development.

\subsubsection{Modern corporate social responsibility}

Modern CSR was born during 1992 Earth Summit in Rio de Janeiro when United Nations sponsored recommendations on regulation were rejected in favour of a manifesto for voluntary self-regulation put forward by a coalition of companies called the World Business Council for Sustainable Development (WBCSD). Its version of events was endorsed by the US, the UK and other Western governments. The British government for example, is still a vocal supporter of voluntarism. Such resistance to regulation seem to have left the worst corporate abusers effectively unrestrained and the victims of their actions adequate means of redress. Whatever responsible initiatives companies choose to carry out on their own behalf binding international standards of corporate behavior must be established to guarantee that the rights of people and the environment in developing countries like Nigeria are properly protected. It is hence recommended that there should be international regulation backed up by national legislation, to ensure the enforcement of real social responsibility on the corporate world. Introducing the threat of prosecution and legal action with resulting detailed disclosure of company documents would create powerful incentives for companies to behave responsibly. At a national level, Government should:

- Adopt new laws to make corporate social and environmental reporting and disclosure mandatory for British companies including the disclosure of payments to overseas government, information on the social and environmental impact of overseas operations and details of legal actions against companies.

- Frame new responsibilities for companies' directors to give them a 'duty of care' for communities and their environment, making them legally accountable for the actions of their companies overseas.

- Change the law to enable people harmed by British companies' overseas operations to seek redress in UK court and to provide the resources to enable them to do so.

\subsubsection{What drives corporate social responsibilities?}

\section{A. Defending public image}

If companies behave improperly, they can be got at through the court of international public opinion. The first CSR initiatives were a response to public pressure and media exposure of poor company behavior. CSR was supposed to show that companies were capable of cleaning up their act. Prof. Michael Porter of the Harvard Business School argues that CSR is all defensive effort, a PR games in which companies primarily react to deal with the critics and the pressure from activists.

\section{B. Attracting investors}

Companies that proactively engage with sustainable development agenda and its advocate in the investment world should generate support, interest and understanding among investors. This will ultimately 
ascribe a premium to share price. CSR makes companies attractive to both mainstream investors and to the fast growing ethical-investment sector. Many investors now believe that social and environmental risk management improves a company's market value in the long term.

\section{Permission to operate}

CSR has, of late become a vital component in companies' effort to gain approval for projects carrying significant political and social risks.

\section{Lobbying against regulations}

"one of the key functions of CSR is to enable further deregulations by pointing to the involvement of business in ethical and sustainable activities and to indicate that multi-stakeholder dialogue with civil society obviates the need for binding regulation" (David Miller, Sterling Media Research Institute). I believe that companies' voluntary measures can help improve private-sector behavior. But voluntary activity is no substitute for regulation and there is evidence that companies that espouse voluntary approaches to meeting social and environmental standards are also involved in resisting external regulation, especially by government.

\subsubsection{Implementation of corporate social responsibilities in Nigeria}

Annually, limited liability companies in Nigeria give reports of their social responsibility efforts. These are in four major identifiable areas; viz:

a. The immediate environment of the company where the interests of the neighbours of the given companies are taken care of as much as is practicable (Bello, 1988).

b. Locating worthy national or state activities to support. In this respect, educational, sporting and cultural activities are sponsored by companies as forms of social responsibility. Also, scholarships, training facilities, and other forms of support are often provided for students.

c. Responding to major disasters. Such disasters may originate from nature or it may be accidental like the bomb explosion at the Ikeja cantonment on Sunday, January 27, 2002. In the oil industry, there had been several reported cases of oil spills damage farmlands, crops, forests and water. Others like fire, flood, drought and erosion are also responded to. Various types of materials are made available to victims of such disasters.

d. Diversification of activities to areas of importance in the nation's economic development. For example, Guinness plc invested funds in two major eye clinics in Nigeria, and Texaco Oil Producing and Marketing Company diversified into agricultural activities of cultivating cassava and processing Garri [Cassava flour].

Before the United Kingdom developed its CSR policy, Gordon Brown, prior to becoming the prime Minister said; today CSR goes far beyond the old philanthropy of the past, donating money to good causes at the end of the financial year and is instead an all year round responsibility that companies accept for the environment around them... now we need to move towards a challenging measure of corporate responsibility, where we judge results not just by the input but by its outcomes: the difference we make to the world in which we live, and the contribution we make to poverty reduction" (Corporate Social Responsibility - A Government Update:

There is no doubt the committee saddled with the responsibility of developing a CSR policy for Nigeria will learn from the countries (especially developing ones) that have adopted and are implementing such policies successfully. Prior to the above declaration of the Federal Government, Nigeria did not have a CSR policy. Several companies operating here took the initiative to develop a CSR guideline or code for themselves. It is not out of place for a study to have found that indigenous firms perceive and practice CSR as corporate philanthropy aimed at addressing socio-economic development challenges in Nigeria. This finding confirms that CSR is a localized and socially embedded construct, as the 'waves', 'issues' and 'modes' of CSR practices identified amongst indigenous firms in Nigeria reflect the firms' responses to their socio-economic context" (Amaeshi, 2006).

\subsubsection{Corporate social responsibility in Nigeria}

The development of CSR in Nigeria can be traced to the colonial period when the European corporations operated in the country. Then the concept of shareholders theory was predominantly pursued by the premier European corporation called Royal Niger Company (RNC) chartered in 1886 (Amaeshi, Adi, Ogbechie and Amao,2006). Shareholder theory defines the primary duty of a firm's managers as the maximization of shareholders wealth (Berle and Means, 1932; Friedman, 1962). The corporate philosophy of the RNC in Nigeria during this period exemplified shareholder perspective of the firm stated above. Between 1885 and 1900 , the company provided casual employment for few indigenes in its postal system in Akassa in 1887, Calabar in 1891, Burutu in 1897 and Lokoja in 1899. The postal system was established primarily for conveying mails 
from its trading stations located in these commercial centres to and from Lagos by a weekly mail boat (Amaeshi, et. al.,2006).

The successor of RNC, the United Africa Company (UAC) was formed in 1919 by a merger between two British trading companies active primarily in West Africa; the Niger Company and the African and Eastern Association. UAC's corporate philosophy was designed to maximize shareholders' profits in line with the concept postulated by Friedman (1962). The policy focused on the restoration of damaged infrastructure, such as shelters, local markets, clinics, roads, hospitals, schools, colleges, universities, airports, etc., in order that the people might be able to recommence their lives as swiftly as possible (Gowon, 2007).

Prior to the 1990s, corporate entities in Nigeria viewed their primary duty as the maximization of shareholders wealth in line with Berle and Means (1932) and Friedman (1962). However, beginning from the 1990s, corporate citizenship dimension of corporate social responsibility began to emerge in Nigeria. Davenport (2000), states that "corporate citizenship became a commonly used term by practitioners" in the 1990s; and this is true for Nigeria. Prior to time, companies in Nigeria did not appreciate need to enhance their reputation through the practice of CSR. The tempo for the implementation of CSR activities gathered momentum, especially among the oil companies, with the internationalization of the conflict between the Ogoni people and the Shell Petroleum Development Company (SPDC) in 1992 (Kretzman, 1995). The Ogoni-SPDC's crisis led to a shift in companies' attitude to CC and CSR in Nigeria. Most companies have since realized the potential impact of CSR on corporate reputation, safety of corporate assets and corporate performance (Lewis, 2003; Garone, 1999).

\subsubsection{Historical background of Globalcom, MTN and Etisalat}

\subsubsection{Historical background of Globacom Nigeria Limited:}

Globacom Limited is a Nigeria multinational telecommunication company. Glo is a privately owned telecommunication company that started operations on the $29^{\text {th }}$ August, 2003 in Nigeria. Globacom is privately owned by Mike Adenuga Group which consists of Equitorial Trust Bank, Conoil Plc., and a petroleum marketing company producing a crude exploration company. The sole aim of introducing and lunching Globacom in Nigeria on the $29^{\text {th }}$ of August, 2003 was to provide telecommunication service to the people of Nigeria as a means of solving the problem of inadequate communication flow.

Although Glo Mobil was the fourth telecommunication operator in Nigeria, within seven years of the company's operation, its subscriber base has grown to over 25 million. Glo has an estimate of over 25 million subscribers. It has a reputation as one of the fastest growing multinational carrier in the world and the vision for Glo is to be the biggest and best carrier in Africa. Globacom currently operates in four countries in West Africa namely Republic of Benin, Ghana, Ivory Coast and Nigeria. Its Headquarter is in Lagos, Nigeria because it is 100 percent a Nigerian owned company.

According to Globacom Annual Report (2009:6), in August, 2003, Glo Mobile was launched in Nigeria and it introduced lower tariffs, pay per second billing and along other value added services. Glo Mobile is a subsidiary of Glo, its Glo Mobile Network Unit. Globacom ability to become the best telecommunication company in Africa and all over the world is due to the strategies they design in other to carry out their business smoothly. An example of their strategic business units are, Globacom Broad Access, Glo Gateway, Glo 1 Submarine cable, etc. In 2005, Glo Mobile introduced Glo fleet manager which is the most comprehensive Vehicle Tracking solution offered to save time and money. Glo fleet manager helps managers, transporters fleet operator manage their fleet effectively and efficiently. They also introduced the Glo Mobile Internet Service which provides subscribers with speed access to all popular Internet sites which have been customized for mobile phone browsing. The company in 2006 introduced Black Berry (A) which is the leading wireless solution that keeps mobile professionals around the world connected to people and information. In 2009, Globacom launched Blackberry prepaid service which gives subscribers options to pay daily, weekly or monthly for the service. The company now provides coverage to over 85 cities and towns and well over 5000 communities and villages spinning every geo-political zone and 36 of Nigeria's States.

Globacom products and services are available at its friendship centers which have a structure and some departments. It also have nationwide network of dealership, banks and convenience channels where its products are sold. Under the chairmanship of Otunba Michael Adeniyi Ishola Adenuga Jr., Globacom has turned out to become the fastest and best telecommunication industry in West Africa. Recently, in June, 2008, Glo mobile was launched in Republic of Benin. Glo Mobile showed unprecedented growth through sales of 600,000 Sim Cards in the first ten days of operation. Glo acquired an operating license through its Glo Mobile division in Ghana and currently has about 11 million subscribers in Ghana, and in 2009, the company acquired submarine cable landing rights and international gateway services in Ivory Coast.

Globacom Nigeria Limited is a leading telecommunication company in Nigeria, which has been at the forefront of promoting sustainable development and high standards of corporate governance and is one of the few signatories that keep date to the convention of business integrity. According to Frank Nweke, (2006.5. 
guardian newspaper) "Glo is an authentic Nigeria Company. What is has achieved in the past years demonstrates great potentials, great opportunities, drive for excellence and commitment to Nigeria". The Nigeria Communication Commission awarded the company as the second national operator driven by the success of Globacom in Nigeria.

\subsubsection{Historical background of MTN}

MTN Nigeria is the largest member of the MTN group, a South African company with many subsidiaries spread across the world (21 countries in Africa and the Middle East). In Nigeria, the company just marked 10 years of operations (August 2011) and has expressed appreciation to all and for good reason too. With all the billions of dollars it has made as profit over the last 10 years it's the least they can do. The company's vision is to be the country's leading provider of telecommunications services while their mission is to provide $1^{\text {st }}$ class network quality, customer service and value.

MTN Communications Ltd was one of 3 initial GSM companies licensed by the NCC to provide telecoms services to the Nigerian public. It commenced operations in August 2001 and has ever since been the biggest Telecoms companies and one of the largest in all of Nigeria. Ever since coming on board the Nigerian Telecommunications market in 2001, MTN Nigeria has made appreciable impact on the lives of Nigerians. The company has invested billions of dollars in Telecoms Equipments and infrastructure providing sub stations, base stations and other amenities both in urban and rural areas in Nigeria. With all these investments, MTN has made socio economic life a lot easier for Nigerians. That way it has created thousands of jobs directly and hundreds of thousands more indirectly. MTN's staff are among the best paid workers not only in the IT/Telecoms field but in the entire country as a whole.

The company has numerous products and services which it offers the Nigerian public and they include; various prepaid call plans like MTN Funlink Reloaded, MTN Bundles, MTN happy Hour, MTN Family and Friends Expanded, MTN Super Saver among others.Also the company provides services such as; Internet Browsing, International roaming (which allows Nigerian subscribers to use their lines in selected countries when not in Nigeria), Enterprise Solutions and Airtime services. But by far the most common among its services is internet browsing from which we have the MTN Blackberry Service, Data bundles, Data Usage, MTN Video Calling, MTN F@stlink, MTN GPRS, MTN Mobile internet and so on. Perhaps among all mobile phone networks in Nigeria, MTN is the most widely spread in terms of coverage and availability. With over 35 million subscribers and counting, it is clearly the preferred network of choice among Nigerians.

\subsubsection{Historical background of Etisalat}

Etisalat is a multinational, blue-chip organization with operations in 15 countries across the Middle East, Africa and Asia. Since its inception in 1976, Etisalat has been at the forefront of the Middle East's technological revolution. Over the last forty years, it has developed and grown to become one of the world's leading telecommunications companies. Etisalat focuses on delivering innovative solutions to transform the communities in which it operates and accelerate social development and economic growth. This has been underpinned by its commitment to actively develop and engineer platforms for growth within the local markets in which it operates. Etisalat's international acquisition programme began in earnest in 2004 by winning the second mobile license, and the first $3 \mathrm{G}$ license in Saudi Arabia.

Since then the company has witnessed rapid expansion, positioning Etisalat as one of the world's fastest growing operators, with its subscriber numbers rocketing from 4 million in 2004 to over 139 million at the end of 2012. Etisalat now has access to a population of about seven hundred million people, and its satellite network provides services to over two thirds of the planet's surface. For nearly 40 years, Etisalat has helped the UAE sustain its position as the region's hub for business, trade and foreign investment by providing reliable and high quality services. It is one of the global telecommunication industry's innovation pacesetters - powering its home country into the Top 10 nations list by providing the latest technologies first.

Etisalat is a pioneer in next-generation networks for both fixed line and wireless connections. The company deployed a nationwide fibre optic network in the UAE, which led to Abu Dhabi being the world's first city to be covered by a powerful, high-speed fibre network. Etisalat also launched $4 \mathrm{G}$ mobile services in the UAE, and today operates the Middle East's largest LTE network where population coverage exceeds 82 per cent. Presently Etisalat offers both the Middle East's fastest fixed line broadband service with speeds of up to $100 \mathrm{Mbps}$ to the home, and the highest speed mobile broadband connectivity. In 2012, Etisalat succeeded in completing the highest 4G LTE speed test in the world, reaching $300 \mathrm{Mbps}$. This lightning-fast speed is a breakthrough for the international telecommunications industry and establishes Etisalat as a global leader in mobile broadband. This technological expertise has helped Etisalat capture significant market share as it expands across the region, most notably in Egypt and Saudi Arabia, where the introduction of mobile broadband services, including video call and mobile TV, has changed market dynamics and provided affordable internet access for millions. Etisalat is pioneering several advanced 'green' technologies and is a regional leader in 
providing environmentally friendly information and communication solutions. This includes smart building technologies, the latest Machine-to Machine (M2M) solutions and the deployment of alternative power within its regional networks. Etisalat is also ensuring that its infrastructure meets the highest international standards; its fibre optic network in the UAE is expected to reduce carbon emissions and energy consumption by over 80 per cent and 70 per cent respectively.

Etisalat is committed to the principles of corporate social responsibility and is partnering with many governments and non-government organisations to increase access to education and health care via technology. Etisalat's innovative services have received over 60 regional and international accolades since 2008 including an unprecedented three GSMA Global Mobile Awards at Mobile World Congress in March 2012 for two of its transformational initiatives: The Mobile Commerce cashless payment system using Near Field Communications (NFC) technology, and The Mobile Baby mHealth platform, a remarkable pre-natal application deployed in subSaharan Africa that allows medical practitioners to send ultrasound images, video clips and 3D scans from ultrasound machines for remote medical analysis via mobile broadband. Moreover, Etisalat has been named 'Best Overall Operator' in the Middle East 10 times since 2006, and was named Best International Carrier at the World Communications Awards in 2008.

\subsection{Theoretical framework}

\subsubsection{Stakeholder theory}

According to Donaldson and Preston (1995) as cited in Bessong and Tapang (2012), the concept of agency theory is narrow. This is because they identify shareholders as the only interest group of a corporate entity necessitating further exploration. By expanding the spectrum of interested parties, Mitchel, Wood and Agle, (1997) argue that, the stakeholder theory stipulates that, a corporate entity invariably seeks to provide a balance between the interests of its diverse stakeholder in order to ensure that each interest's constituency receives some degree of satisfaction. In separate contribution, According to Elkington (2002), stakeholder theory appears better in explaining the role of corporate governance than the agency theory by highlighting the various constituent; employees, banks, governance, relevant stakeholders. Related to the above discussion, Freeman and Evan (1990) provide a comprehensive review of the stakeholders' theory of corporate governance which points out the presence of many parties with competing interests in the operations of the firm. They also emphasize the role of non-market mechanisms such as the size of the board, committee structure as important to firm performance.

Stakeholder theory has become more prominent because many researchers have recognized that the activities of a corporate entity impact on the external environment requiring accountability of the organization to a wider audience than simply its shareholders (i.e. stakeholders). For instance, Savage, Nix, Whitehead and Blair, (1991) proposed that companies are no longer the instrument of shareholder alone but exist within society and therefore, have responsibilities to that society. One must however point out that large recognition of this fact has rather been a recent phenomenon. Indeed, it has been realized that economic value is created by people who voluntarily come together and corporate to improve everyone's position (Freeman, 2004).

Based on the explanations offered by the frameworks, it became pertinent that management of corporate entity should at all time put in measures to ensure quality standards in all aspects of management process to enable stakeholders to keep the benefit of their investment.

\subsection{Empirical Review}

Amaeshi (2006), revealed that Nigerian firms see and practice CSR as corporate philanthropy. The research found that this construct of CSR was a reaction of indigenous firms to the peculiar socio-economic realities of Nigeria. They also opined that this conception of CSR could be connected to the traditional sociocultural heritage of Nigerian firms and prevalent religious influences in the country. The socio-cultural belief in Nigeria promotes the philosophy of being one's brother's keeper; the haves are expected to impact positively on the have-nots. Waves, issues, and modes of CSR engaged in by the indigenous firms also mirrored Nigeria's peculiar socio-economic conditions. Multinationals, on the other hand, based their perception and practice of CSR on the mandates from their home countries, or on those areas that directly impact on their business activities. However, some multinationals and local firms now have separate Foundations that have taken CSR beyond plain philanthropy.

Extensive research work done on CSR in Nigeria by New Nigeria Foundation corroborated the findings by Amaeshi (2006). New Nigeria Foundation's (NNF) study showed that CSR had been carried out mainly as philanthropic activities and, as a result, "corporate contributions had remained largely unregulated, unsupervised and unguided, depending entirely on the whims, caprices and generosity or otherwise of particular corporate executives in office". NNF's study focused on financial CSR, CSR in the workplace and market place, as well 
as in the community and environment. Basically, it was found that while companies had made some improvements in various aspects of CSR as defined for the study, a lot still needed to be done. This is especially so for indigenous firms which were found to be lagging behind their multinational counterparts. A major beneficiary of CSR in Nigeria is the agriculture and rural development sector. An overview of the contributions of CSR to this sector is provide herewith with emphasis on participants, partnerships and objectives, scope of coverage, mode of delivery and level of contributions. The Three Components of Sustainability - The Triple Bottom Line Sustainable development is development that meets the needs of the present without compromising the ability of future generations to meet their own needs (World Commission on Environmental and Development, 1987). The triple bottom line is considering that companies do only have one objective, profitability, but that they also have objectives of adding environmental and social value to society (Crane \& Matten, 2004).

The concept of sustainability is generally regarded as having emerged from the environmental perspective is about how to manage physical resources so that they are conserved for the future. Therefore, economic sustainability is about the economic performance of the organization itself. A broader concept of economic sustainability includes the company's impact on the economic framework in which it is embedded. The development of the social perspective has not developed as fast as the environmental and economic perspectives (Bessong \& Tapang, 2012). The key issue in the social perspective on sustainability is that of social justice. It can be seen from above that economic and environmental sustainability involved in the concept of externalities is mostly engendered in the importance placed by comparatives in the concept of social responsibilities. The European Foundation for Quality Management [EFQM] defines CSR as "a whole range of fundamentals that organizations are expected to acknowledge and to reflect in their actions. It includes among other things respecting human rights, fair treatment of the workforce, customers and suppliers, being good corporate citizens of the communities in which they operate and conservation of natural environment". These fundamentals are seen as not only morally and ethically desirable ends in themselves and as part of the organization's philosophy; but also as key drivers in ensuring that society will allow the organization to survive in the long term, as society benefits from the organization's activities and behavior" (The EFQM Framework For Social Responsibility, 2004). CSR is the concept that an organization needs to consider the impact of their operations and business practices on not just the shareholders, but also its customers, suppliers, employees, members of the community it operates in, and even the environment. It is a way of saying thank you and expressing appreciation to all stakeholders in the business. It is a conscious effort to give back to the society in which the corporation has benefitted immensely.

\section{Material And Methods}

Research design is the blueprint for the collection, measurement and analysis of data (Etuk, 2010). In this study the researcher made use of the ex-post facto design. According to Etuk (2010), ex-post designs do not provide the investigator the opportunity to control the variables mainly because they have already occurred or cannot be manipulated. The design will help the researcher to find out, describe and explain existing problem and draw generalization on the population based on the data collected from the respondents.

According to Etuk (2010), population comprises all the elements that form the basis of analysis. The population of this study comprises of $199,000,000$ subscribers of the three main multinational telecommunication companies in Nigeria namely Globacom, MTN and Etisalat. This was obtained as follows:

Table 3.1: Determination of the population Size

\begin{tabular}{|c|l|c|}
\hline S/N & \multicolumn{1}{|c|}{ Telecom companies } & Number of subscribers \\
\hline 1 & GLOBACOM Nigeria & $25,000,000$ \\
\hline 2 & MTN Nigeria & $35,000,000$ \\
\hline 3 & ETISALAT Nigeria & $139,000,000$ \\
\hline & \multicolumn{1}{|c|}{ Total } & $199,000,000$ \\
\hline
\end{tabular}

Source: Telecom Individual annual reports, 2016

The sample size of the study constituted 400 customers obtained using the Taro Yamane formula in determining sample size. According to Yamane (1967) as cited in Bessong and Tapang, 2012, the sample size is determined as follows:

$$
\begin{aligned}
& \mathrm{n}=\mathrm{N} /\left[1+\mathrm{N}\left(\mathrm{e}^{2}\right)\right] \\
& \text { Where; } \mathrm{n}=\text { Sample size } \\
& \mathrm{N}=\text { Population size }=199,000,000 \\
& \mathrm{e}=\text { Error term }(0.05 \text { on the basis of } 95 \% \text { confidence level }) \\
& \mathbf{n}=\frac{199,000,000}{\left.1+\left(199,000,000 \times 0.05^{2}\right)\right]}
\end{aligned}
$$




$$
\begin{aligned}
& \mathbf{n}=399.994 \text { Approximately } 400 \\
& \mathbf{n}=\mathbf{4 0 0} \text { subscribers }
\end{aligned}
$$

Table 3.2: Sample size determination

\begin{tabular}{|c|l|c|l|}
\hline \multicolumn{3}{|c|}{$\begin{array}{c}\text { Number of } \\
\text { Customers }\end{array}$} \\
\hline 1 & GLOBACOM Nigeria & $25,000,000$ & $\frac{25,000,000 \times 4}{199,000,000}$ \\
\hline 2 & MTN Nigeria & $35,000,000$ & $\frac{35,000,000 \times 4}{199,000,000} \times 100=$ \\
\hline 3 & ETISALAT Nigeria & $139,000,000$ & $\frac{139,000,000 \times 400=280}{199,000,000}$ \\
\hline & Total & $199,000,000$ & \\
\hline
\end{tabular}

Source: Researcher's Estimation, 2016

\section{Findings}

Based on the empirical analysis, the study revealed that economic expectation of CRS performance do has a significant effect on stakeholder's perception. The study also revealed that legal expectation of CRS performance do has a significant effect on stakeholder's perception. The study further revealed that ethical expectation of CRS performance do has a significant effect on stakeholder's perception. The study finally revealed that discretional expectation do has a significant effect on stakeholder's perception. This result is supported with the work of Bessong and Tapang (2012).

\subsection{Conclusion}

\section{Conclusion And Recommendations}

Although corporate social responsibility performance was found to have a significant influence on stakeholder's perception, telecommunication firms that observed and ensured proper corporate social responsibility practices are more or less likely to reduce the nuisance brought about by waste products generated by the firm and often brings about positive social responsibility rating, image and acceptability of the firm within its operating area. While behaving in a socially responsible way normally raises the cost profile of a firm, there have been evidence, although not unchallenged, that firms that do so tend to enjoy better long run corporate performance, arising mostly from the support, friendliness and peace they often experience in their operating environment.

\subsection{Recommendations}

Arising from the findings and conclusion of the study, the following recommendations were made:

1. Firms should institute proactive waste management systems and structures that ensure that the disposals of the harmful by-products in every aspect of their operations are properly handled. Such systems need not be compelled by government regulation, but should be voluntarily provided by the firms themselves. The long run benefits of avoidance of fines and penalties justify such expenditure.

2. Corporate social responsibility projects should be provided by firms especially within and for the benefit of their host communities, especially as government has not been very successful in meeting the basic needs of most communities. Typical areas of intervention for firms in Nigeria include education, health and physical infrastructure support. Such actions ensure that a firm enjoys a positive image and good neighborliness from its host community.

\section{References}

[1]. Ajadi, J.A. (2006). Mobilizing small-scale savings through co-operative savings and credit associations. In V.O.

[2]. Amaeshi, K. M., Adi, A.B. C., Ogbechie, C. \& Amao, O. O. (2006). Corporate Social Responsibility in Nigeria: Western Mimicry or Indigenous Influences? Available at: SSRN: http://ssrn.com/abstract $=896500$

[3]. Bagnoli, M. and Watts, S. (2013). "Selling to socially responsible consumers: Competition and the private provision of public goods," Journal of Economics and Management Strategy, 12: 419-445.

[4]. Baron, D. (2001). "Private Politics, Corporate Social Responsibility and Integrated Strategy," Journal of Economics and Management Strategy, 10: 7-45.

[5]. Bello, J. B. (1988): "Self interest and community" J. Bus. ethics. 7:453-458.

[6]. Berle, A.A. and Means, G.C. (1932). The Modern Corporation and Private Property, New York: Macmillan.

[7]. Bessong, P. K. \& Tapang A. T. (2012). Social responsibility accounting cost and its influence on the profitability of Nigerian Banks. International Journal of Financial Research, 3 (4), 33-4.

[8]. Black, P. C. (2010). Public-Private Partnership for Agricultural Production and Food Security.The Sixth School Annual Lecture Series of the School of Agriculture and Agricultural Technology, The Federal University of Technology. Akure, Nigeria

[9]. Bowen, H. R. (1953): Social Responsibilities of the businessmen. NewYork: Harper and Row Publishers Incorporated.

[10]. Buchholz R (1991): "Corporate responsibility and the Good Society, from Economy to Ecology" Business Horizon, July-August. p. 19

[11]. Carroll, A.B. (1979). A Three Dimensional Model of Corporate Performance. Academy of Management Review， 4(4):497-505 
[12]. Chandler, G. (2001). "Defining Corporate Social Responsibility," Ethical Performance Best Practice, Fall 2002, cited in "What is Corporate Social Responsibility?" Catalyst Corporation and U.S. Agency for International Development (USAID), http://www.rhcatalyst.org/site/DocServer/CSRQ_A.pdf? docID=103

[13]. Clarkson M,(1995): "A stakeholder framework for analyzing and evaluating Corporate Social Performance, Academy of management review. 20: 92-117.

[14]. Crane, A. \& Livesey, S. (2003) 'Are you talking to me?: Stakeholder communication and the risks and rewards of dialogue, in J. Andriof, S. Waddock, B. Husted, \& S. S. Rahman (Eds.), Unfolding Stakeholder Thinking 2, Sheffield, UK: Greenle af Publishing, pp. 39-52.

[15]. Davenport, K. (2000) Corporate Citizenship: A Stakeholder Approach for Defining Corporate Social Performance and Identifying Measures for Assessing It. Business \& Society, 39 (2), 210-219

[16]. Donaldson, T. and Preston, L. \{1995). The Stakeholder Theory of the Corporation: Concepts, Evidence, and Implications, Academy of Management Review, 20: 65-91.

[17]. Etuk, E. J. (2010). Business Research Methods: Concepts, processes and applications. Calabar. University of Calabar Press.

[18]. European Commission (2006). COMMUNICATION FROM THE COMMISSION Concerning Corporate Social Responsibility: A business contribution to Sustainable Development, July http://trade.ec.europa.eu/doclib/docs/2006/february/tradoc 127374.pdf. Retrieved January 12, 2011

[19]. Federal Republic of Nigeria (2000). Niger-Delta Development Commission (Establishment etc) Act, 2000 Act No 6. Available at: law.org/Niger Delta Development Commission (Establishment\% 20etc)Act2000.htm (accessed 23-01-2011)

[20]. Federal Republic of Nigeria (2005). Niger Delta Regional Development Master Plan. Available at: http://www.nddc.gov.ng/NDRMP\%20Chapter\%202.pdf (accessed 22-02-2011)

[21]. Firth, D. K., Fung, T and Rui, M. (2008). A History of Nigeria, Cambridge: University Press

[22]. Florackis, G. H \& Ozkan (2004). Strategic Management: A Stakeholder Perspective, Englewood Cliffs, NJ: Prentice Hall.

[23]. Fombrun, C. and Shanley, M. (1990). What's in a Name? Reputation Building and Corporate Strategy, Academy of Management Journal, 33: 233-258.

[24]. Fraoman J(1997): Socially Irresponsible and Illegal Behaviour Shareholders wealth. Business and Society.

[25]. Freeman, R. E. (2004), The Stakeholder Approach Revisited. Zeitschrift Für Wirtschafts- Und Unternehmensethik, 5, 228-241.

[26]. Freeman, R. E. \& Evan, D. R. (1990). Business, Ethics and Society: A Critical Agenda. Business \& Society, 31, 9-17.

[27]. Freeman, R. E. \& Evan, W. M.(1993) ‘A Stakeholder Theory of the Modern Corporation: Kantian Capitalism', in T. L. Beauchamp \& N. E. Bowie (Eds.), Ethical Theory and Business: Englewood Cliffs, New Jersey: Prentice-Hall, $\quad$ pp. 75-84. edman, M., (1962). Capitalism and Freedom, Chicago: University of Chicago Press.

[28]. Garone, S. (1999). The Link between Corporate Citizenship and Financial Performance, Report No. R-1234-99-RR, The Conference Board. Available at: http://www.conference-board.org/publications/publicationdetail.cfm?publicationid=415 (accessed 29-01-2011)

[29]. Gowon, Y. (2007, June) Governance Challenges in Crisis and Post-conflict Countries, United Nations 7th Global Forum,Vienna, Austria

[30]. Harris, O. and Poll, K. (1993) Policies and Programmes for Poverty Reduction in Rural Nigeria An Interim Research Report Submitted to The African Economic Research Consortium (AERC), Nairobi for the Second Phase Collaborative Poverty Research Project. Available At: http://www.sarpn.org.za/ documents/d0002274/Poverty_reduction_Nigeria_Oct2005.pdf (Accessed 23-012010)

[31]. Jones, T. (1995). Instrumental Stakeholder Theory: A Synthesis of Ethics and Economics. Academy of Management Review,20: 404-437.

[32]. Kenneth, C.S., Andrews, O. E. D. and Steiner, R. N. (1977) Resource-Use Efficiency and Return to Scale in Smallholders Rubber Farming System in Edo State, Nigeria. Journal of Human Ecology, 28(3), 183-186.

[33]. Kington, E. I. (2002). The social responsibility of business is to increase its profits. New York Times Magazine September, 13.

[34]. Koontz, A. and O'Donnel (1968). Sustainability, accountability and corporate governance: Exploring multinationals' reporting practices. Business Strategy \& the Environment (John Wiley \& Sons, Inc), 17(1), 1-15. doi:10.1002/bse.511

[35]. Kretzman, S. (1995). “Nigeria's 'Drilling Fields': Shell Oil's Role in Repression,” Multinational Monitor, 16:1-2

[36]. Lee, M.P. (2008). A Review of the Theories of Corporate Social Responsibility: Its Evolutionary Path and the Road Ahead. International Journal of Management Reviews, Vol. 10 (1):53- $\quad 73$. doi: 10.1111/j.1468-2370.2007.00226.x. Available at: http://www.scribd.com/doc/30317893/A-Review-of-the-Theories-of- Corporate-Social-Responsibilityi396059 (accessed 25-012011)

[37]. Lewis, S (2003). Reputation and Corporate Responsibility, Journal of Communication Management, 7(4), 356 - 364

[38]. Lohman T.E. and Steinholtz, O.E. (2013). A perspective of partial credit guarantee schemes in developing countries: A case study of the Nigerian agricultural credit guarantee scheme funds. A paper delivered at The World Bank conference on Partial Credit Guarantee Schemes held at the World Bank Main Building, Washington, D.C, USA, March 13-15, Pp. 35

[39]. Macmillan, E. (2005). Trend performance in credit financing of rural business activities in Nigeria: A case study of community banks in Ibadan, Oyo State. International Journal of Agriculture and Rural Development, 7 (1): 50- 60.

[40]. Mate, K. (2002) Capacity Building and Policy Networking for Sustainable Mineral-Based Development, Report prepared for UNCTAD under Project $\mathrm{M}$ of the UN Development Account. Available at http://www.naturalresources.org/minerals/latam/monterrey.htm (accessed 23-01-2011)

[41]. Mathison, E.E. (2003). "The Ogoni Uprising: Oil, Politics, Minority Agitation, and the Future of the Nigerian State." African Affairs, 94, 325-44.

[42]. McGuire (1963) Business and Society. New York, McGraw-Hill.

[43]. McWilliams, A. and Siegel, D. (2001). Corporate Social Responsibility: A Theory of the Firm Perspective. Academy of Management Review, 26(1), 117-127.

[44]. Miles, J. (1987). Disinvestment from South Africa: They Did Well By Doing Good, Contemporary Economic Policy, 76-86.

[45]. Mitchell, R. K., Agle, B. R \& Wood, D. J. (1997),Toward a Theory of Stakeholder Identification and Salience Defining the Principl e of Who and What Really Counts. Academy of Management Review, 22, 853-886.

[46]. New Nigeria Foundation (2007). Corporate Social Responsibility Performance in Nigeria: An Evaluation, Lagos: New Nigeria Foundation.

[47]. Pedersen, F. and Huniche, O., (2006). Re-Engineering Agriculture for Enhanced Performance through Financing, Journal of Economics, Finance and Administrative Science, 15(29), 35-49 
[48]. Posk, B. S., Omotesho, O.A, Tsoho, A. B. and Ajayi, P. D. (1999). An Economic Survey of Rural Infrastructures and Agricultural Productivity Profiles in Nigeria European Journal of Social Sciences - 7 (2): 158-171

[49]. Savage, G. T., Nix, T. W., Whitehead, C. J., \& Blair, J. D. (1991), Strategies for assessing andmanaging organizational stakeholders $'$. Academy of Management Executive, 5, 61-75.

[50]. Social responsibility (2004). Paper presented at the Academy of management conference, Denver. August11-14.

[51]. Visser, W. (2006). Revisiting Carroll's CSR pyramid. In: E.R. Predersen and Huniche, M. Available at http://www.waynevisser.com/chapter_wvisser_africa_csr_pyramid.pdf (accessed 25- 01-2011)

[52]. Wood, D.J. (1991). Corporate Social Performance Revisited. Academy of Management Review, 16(4): 691-718.

[53]. World Business Council for Sustainable Development (2000). Corporate social responsibility: making good business. http://www.wbcsd.org/DocRoot/IunSPdIKvmYH5HjbN4XC/csr2 000.pdf. Retrieved October 25, 2010.

[54]. World Commission on environmental Development (1987). Business Case for Sustainable Development: Making Difference Towards the Johannesburg $\quad$ Summit 2002 and Beyond. Available at: http://www.wbcsd.org/DocRot/rZNj49UF0okxGvdLDte/business- case.pdf (accessed 25-01-2011)

[55]. World Economic Forum (2003). Global Corporate Citizenship: The Leadership Challenge for CEOs and Boards. Available at: https://members. weforum.org/pdf/GCCI/ GCCCEOstatement.pdf (accessed 25-01-2011).

[56]. Yamane, T. (1967). Elementary sampling theory. Englewood Cliffs, New Jersey: Prentice- Hall, Inc. 